\title{
Faktor-faktor yang mempengaruhi terjadinya Multi Drug Resistance Tuberkulosis (MDR-TB)
}

\author{
Cynthia Devi Aristiana ${ }^{1}$ Magdalena Wartono ${ }^{2}$
}

\begin{abstract}
ABSTRAK
LATAR BELAKANG

Berdasarkan data WHO Global Report 2016, Indonesia berada diperingkat ke-8 dari 27 negara dengan beban MDR-TB terbanyak di dunia. Terdapat 5.100 kasus MDR-TB yang terjadi di Indonesia yaitu 2,8 \% dari kasus baru dan $16 \%$ dari kasus TB yang mendapatkan pengobatan ulang. Banyaknya jumlah kasus MDR-TB yang terjadi melibatkan berbagai faktor yang terkait. Penelitian ini bertujuan untuk menganalisis faktor resiko yang berpengaruh dengan MDR-TB.
\end{abstract}

\section{METODE}

Penelitian ini menggunakan metode observasional analitik dengan disain potong lintang yang dilakukan bulan November 2017-Januari 2018. Subjek penelitian adalah 88 pasien TB yang berobat di Puskesmas Kecamatan Kramat Jati, Kecamatan Makassar, Kecamatan Pasar Rebo, dan Kecamatan Ciracas. Pengambilan data menggunakan kuisioner dan status pasien TB. Analisis data dengan menggunakan uji chi-square dan uji fisher dengan nilai kemaknaan $\mathrm{p}<0,05$ serta odd ratio untuk menentukan besar risiko antara variabel bebas dan variabel terikat.

\section{HASIL}

Motivasi penderita $(\mathrm{p}=0,000 ; \mathrm{OR}=47,500)$, kepatuhan minum obat $(p=0,000 ; \quad O R=10,733)$, konsumsi alkohol $(p=0,000 ; \quad O R=9,059)$, Kebiasaan merokok $(p=0,000 ; O R=7,632)$, dan status gizi $(p=0,005$; $\mathrm{OR}=3,791$ ) mempunyai hubungan yang bermakna dengan MDR-TB.

\section{KESIMPULAN}

Faktor-faktor yang berhubungan dengan timbulnya MDR-TB antara lain kepatuhan minum obat, konsumsi alkohol, kebiasaan merokok dan status gizi.

Kata kunci : MDR-TB, faktor risiko, resistensi sekunder

\author{
${ }^{1}$ Program Studi Kedokteran, \\ Fakultas Kedokteran, \\ Universitas Trisakti \\ ${ }^{2}$ Departemen Anatomi, \\ Fakultas Kedokteran, \\ Universitas Trisakti

\section{Korespondensi:} \\ Magdalena Wartono \\ Departemen Anatomi, \\ Fakultas Kedokteran, \\ Universitas Trisakti \\ E-mail: \\ magdalena_w@trisakti.ac.id
}

J Biomed Kes 2018;1(1):65-74

DOI: 10.18051/JBiomedKes.2018.

v1.65-74

pISSN: 2621-539X / eISSN: 2621-5470

Artikel akses terbuka (open access) ini didistribusikan di bawah lisensi Creative Commons Attribution 4.0 International (CC-BY 4.0) 


\section{ABSTRACT}

\section{Factors affecting the incident of Multi Drug Resistant Tuberculosis (MDR-TB)}

\section{BACKGROUND}

Based on WHO Global Report 2016, Indonesia is ranked 8th of 27 countries with the highest MDR-TB burden in the world. There are 5.100 cases of MDR-TB occurring in Indonesia that is $2.8 \%$ of new cases and $16 \%$ of cases of TB receiving re-treatment. The large number of MDR-TB cases that occur involves a variety of related factors. This study aims to analyze the risk factors that affect the MDR-TB.

\section{METHODS}

This was an observasional analytic study with cross sectional design conducted on November-January 2018. Research subjects were 88 TB patients who were treated at public health community of sub-district Kramat Jati, Makassar, Pasar Rebo, and Ciracas in East Jakarta. The instruments of the research used questionnaire and patient status. Data analysis using chi-square test and fisher test with significance result $p<0,05$ and odd ratio to determine risk level between independent variable and dependent variable.

\section{RESULT}

Smoking habit $(p=0,000 ; O R=7,632)$, alcohol consumption $(p=0,000 ; O R=9,059)$, nutritional status $(p=0,005$; $\mathrm{OR}=3,791)$, patient motivation $(\mathrm{p}=0,000 ; 47,500)$ and medication adherence $(\mathrm{p}=0,000 ; \mathrm{OR}=10,733)$ were associated with MDR-TB.

\section{CONCLUSION}

This study reveals that there is no significant correlation between asthma and depression in the young-adult.

Keywords : MDR-TB, risk factors, secondary resistance

\section{PENDAHULUAN}

Tuberkulosis (TB) adalah penyakit menular yang disebabkan oleh bakteri Mycobacterium tuberculosis. Sebagian besar dari bakteri ini menginfeksi paru, tetapi juga dapat mengenai organ tubuh lain. ${ }^{1}$ Tuberkulosis paru merupakan penyakit menular yang paling berpengaruh sebagai penyebab morbiditas dan mortalitas. ${ }^{2}$ Berdasarkan WHO Global TB Report tahun 2016, TB merupakan penyebab kematian pertama yang disebabkan penyakit menular dan termasuk sepuluh penyakit yang paling mematikan di dunia. Indonesia berada pada urutan ke-3 dari enam negara yang menyumbang $60 \%$ kasus TB di seluruh dunia, setelah Cina dan India. $^{3}$ Berdasarkan data Kemenkes RI, DKI Jakarta menempati urutan ke-4 dari 34 provinsi dengan jumlah kasus TB tertinggi sebanyak 24.775 kasus. $^{4}$

Pengobatan tuberkulosis dilakukan selama enam bulan secara rutin. Pengobatan yang terputus atau tidak sesuai dengan standar DOTS dapat menyebabkan kekambuhan penyakit dan kemungkinan terjadinya resistensi sekunder kuman TB terhadap obat anti Tuberkulosis atau Multi Drug Resistance (MDR). ${ }^{5}$ MDR-TB didefinisikan sebagai resistensinya dua obat anti TB paling penting pada terapi TB lini pertama, yaitu rifampisin dan isoniazid.2 Pengobatan obat yang tidak adekuat pada individu dengan TB akan membunuh sebagian besar bakteri namun akan memungkinkan pertumbuhan sejumlah kecil organisme resisten di dalam populasi bakteri yang timbul. Bila pengobatan yang tidak memadai terus dilakukan maka sejumlah kecil organisme yang telah bermutasi akan memiliki resistensi terhadap obat lain secara berurutan dan berkembang menjadi resistensi terhadap banyak obat anti TB. ${ }^{6}$ Dengan adanya MDR-TB maka masa pengobatan menjadi lebih panjang. Pengobatan dilakukan selama 24 bulan yang terdiri dari 8 bulan fase intensif dan 16 bulan fase lanjutan. ${ }^{7}$

Saat ini, MDR-TB merupakan masalah terbesar dalam pencegahan dan pemberantasan TB di dunia. ${ }^{6}$ Sebagian besar kasus terjadi di Asia dan menyebabkan kematian. ${ }^{8}$ Di tingkat global, Indonesia berada diperingkat ke- 8 dari 27 negara dengan beban MDR-TB terbanyak di dunia. ${ }^{9}$ Terdapat 5.100 kasus MDR-TB yang terjadi di Indonesia yaitu 2,8 \% dari kasus baru dan $16 \%$ dari kasus TB yang mendapatkan pengobatan ulang. ${ }^{3}$

Banyaknya jumlah kasus MDR-TB melibatkan berbagai faktor yang terkait. Menurut Masniari, faktor-faktor seperti 
ketidaktahuan penderita tentang penyakitnya, kepatuhan penderita yang buruk, keteraturan obat yang rendah, motivasi penderita yang kurang memberikan kontribusi terhadap terjadinya MDR-TB. Sedangkan menurut Caminero, beberapa faktor yang dapat menyebabkan MDR-TB meliputi tidak mengimplementasikan DOTS sebagai terapi Tuberkulosis, status gizi, dan tingginya infeksi HIV.5 Selain itu, menurut Balaji dkk, ada beberapa faktor lain yang dapat menyebabkan MDR-TB seperti merokok, konsumsi alkohol, diabetes, umur, dan jenis kelamin wanita. ${ }^{10}$

Berdasarkan uraian diatas, terdapat banyak faktor yang berkontribusi terhadap terjadinya kasus MDR -TB. Oleh karenanya, penulis merasa penting untuk meneliti tentang analisis faktor resiko yang berpengaruh dengan kejadian MDR - TB untuk menurunkan prevalensi kasus MDR-TB yang terjadi di Indonesia.

\section{METODE}

Penelitian ini menggunakan metode observasional analitik dengan desain cross sectional yang dilakukan bulan NovemberJanuari 2018. Subjek penelitian adalah pasien TB yang berobat di Puskesmas Kecamatan Kramat Jati, Kecamatan Makassar, Kecamatan Pasar Rebo, dan Kecamatan Ciracas. Teknik pengambilan sampel yang digunakan dalam penelitian ini adalah consecutive non random sampling.

Kriteria inklusi adalah pasien TB yang sedang menjalani pengobatan OAT fase lanjutan yang berusia 15-50 tahun, pasien dengan status mental baik dan bersedia mengikuti penelitian. Kriteria eksklusi adalah pasien yang terdiagnosis XDR-TB, MDR-TB primer, pasien TB dengan hasil BTA positif pada bulan ketiga fase lanjutan, dan pasien TB kategori 2. Jumlah subjek penelitian sebanyak 88 orang. Bahan dan instrumen yang digunakan untuk pengumpulan data adalah Kuisioner AUDIT (The Alcohol Use Disorders Identification Test), kuisioner MMS (Modified Morisky Scale) untuk menilai kepatuhan minum obat dan motivasipenderita, wawancara pasien untuk menentukan kebiasaan merokok (dengan brinkmann indeks), jenis kelamin dan tingkat pendidikan, data rekam medis untuk menentukan riwayat Diabetes Mellitus dan HIV. Analisis data yang digunakan adalah analisis univariat dan analisis bivariat. Analisis bivariat menggunakan uji chi-square dan uji fisher dengan hasil kemaknaan $\mathrm{p}<0,05$ serta odd ratio untuk menentukan besar risiko antara variabel bebas dan variabel terikat.

\section{HASIL}

Responden yang menjadi sampel dalam penelitian ini adalah penderita TB paru fase lanjutan yang masih melakukan pengobatan selama bulan November-Januari 2018 dengan jumlah responden sebanyak 88 orang.

Hasil penelitian dari total responden yang berjumlah 88 orang, didapatkan sebanyak 28 responden $(31,8 \%)$ terdiagnosis MDR-TB dan 60 responden $(68,2 \%)$ terdiagnosis TB paru non MDR. Jenis kelamin terbanyak adalah laki-laki $(64,8 \%)$ dengan rentang usia 15-35 tahun $(55,7 \%)$. Dari karakteristik tingkat pendidikan, responden dengan tingkat pendidikan tinggi adalah sebanyak 69 orang $(78,4 \%)$.

Dilihat dari karakteristik faktor kebiasaan, lebih banyak responden yang tidak memiliki kebiasaan merokok $(63,6 \%)$ dan yang memiliki kebiasaan konsumsi alkohol hanya sebanyak 15 orang (17\%). Data status gizi terbanyak dari responden adalah normal dengan IMT 18,5-22,9 sebanyak 59 orang $(67 \%)$. Penyakit penyerta lain yang didapatkan adalah 5 orang $(5,7 \%)$ menderita Diabetes Mellitus (DM) dan 4 orang $(4,5 \%)$ menderita Human Immunodeficiency Virus (HIV).

Dari segi tingkat motivasi responden dalam menjalani pengobatan OAT, sebagian besar responden $(26,1 \%)$ masih memiliki motivasi yang. Responden dengan kepatuhan minum obat tinggi $(53,4 \%)$ juga ditemukan lebih banyak dibandingkan responden dengan kepatuhan minum obat rendah. 
Tabel 1. Distribusi karakteristik dari subjek penelitian

\begin{tabular}{|c|c|c|}
\hline Variabel & $\mathrm{N}$ & $\%$ \\
\hline \multicolumn{3}{|l|}{ TB-MDR } \\
\hline $\mathrm{TB}-\mathrm{MDR}$ & 28 & 31,8 \\
\hline TB non - MDR & 60 & 68,2 \\
\hline \multicolumn{3}{|l|}{ Jenis Kelamin } \\
\hline Laki - Laki & 57 & 64,8 \\
\hline Perempuan & 31 & 35,2 \\
\hline \multicolumn{3}{|l|}{ Usia } \\
\hline $15-35$ & 49 & 55,7 \\
\hline$>35$ & 39 & 44,3 \\
\hline \multicolumn{3}{|l|}{ Tingkat Pendidikan } \\
\hline Rendah & 19 & 21,6 \\
\hline $\begin{array}{l}\text { Tinggi } \\
\text { Kebiasaan } \\
\text { Merokok }\end{array}$ & 69 & 78,4 \\
\hline $\mathrm{Ya}$ & 32 & 36,4 \\
\hline Tidak & 56 & 63,6 \\
\hline \multicolumn{3}{|l|}{ Konsumsi Alkohol } \\
\hline Ya & 15 & 17 \\
\hline Tidak & 73 & 83 \\
\hline \multicolumn{3}{|l|}{ Status Gizi } \\
\hline Underweight & 29 & 33 \\
\hline Normal & 59 & 67 \\
\hline \multicolumn{3}{|l|}{ Diabetes Melllitus } \\
\hline Ya & 5 & 5,7 \\
\hline Tidak & 83 & 94,3 \\
\hline \multicolumn{3}{|l|}{ HIV } \\
\hline Ya & 4 & 4,5 \\
\hline Tidak & 84 & 95,5 \\
\hline \multicolumn{3}{|l|}{ Motivasi Penderita } \\
\hline Rendah & 23 & 26,1 \\
\hline $\begin{array}{l}\text { Tinggi } \\
\text { Kepatuhan Minum }\end{array}$ & 65 & 73,9 \\
\hline $\begin{array}{l}\text { Obat } \\
\text { Kepatuhan rendah }\end{array}$ & 41 & 46,6 \\
\hline Kepatuhan tinggi & 47 & 53,4 \\
\hline
\end{tabular}

Tabel 2 merupakan hasil perhitungan uji analisis bivariat antara timbulnya MDRTB dengan faktor-faktor yang dinilai dapat memberikan pengaruh. Berdasarkan nilai Odd Ratio maka dapat disimpulkan dari penelitian ini, faktor motivasi penderita merupakan faktor risiko yang paling tinggi dibandingkan variabel lainnya $(\mathrm{OR}=47,5 ; 95 \% \mathrm{CI}=11,46$ - 196,77) disusul oleh kepatuhan minum obat $(\mathrm{OR}=10,73 ; 95 \% \mathrm{CI}=3,52-32,68)$, konsumsi alkohol $(\mathrm{OR}=9,05 ; 95 \% \mathrm{CI}=2,55$ - 32,1) , kebiasaan merokok $(\mathrm{OR}=7,63$; $95 \% \mathrm{CI}=2,79-20,81)$ serta status gizi $(\mathrm{OR}=$ $3,79 ; 95 \% \mathrm{CI}=1,46-9,83)$.

\section{PEMBAHASAN}

\section{Hubungan jenis kelamin dengan MDR-TB}

Didapatkan jenis kelamin terbanyak pada pasien MDR-TB dan non-MDR adalah laki laki, masing-masing sebanyak 19 orang $(33,3 \%)$ dan 38 orang $(66,7, \%)$. Hasil analisis bivariat dengan uji chi-square didapatkan nilai $\mathrm{p}=0,679$ artinya tidak didapatkan hubungan yang bermakna antara jenis kelamin dengan MDR-TB. Hasil ini serupa dengan penelitian Sarwani ${ }^{5}$ di mana laki-laki lebih banyak menderita MDR-TB dibandingkan dengan perempuan, namun juga tidak didapatkan perbedaan yang bermakna $(\mathrm{p}=0,80)$. Penelitian oleh Munir ${ }^{11}$ pada 101 pasien MDR-TB di RS Persahabatan tahun 2009 juga didapatkan sebanyak 53 orang (52,5\%) pasien MDR-TB adalah laki-laki.

Jenis kelamin laki-laki rentan terhadap TB karena perannya sebagai kepala keluarga yang lebih banyak beraktifitas di luar sehingga mudah untuk tertular TB. Banyaknya aktivitas yang dilakukan dan cenderung sulit diatur menjadi penyebab kelalaian menjalani pengobatan sehingga menjadi MDR-TB. ${ }^{12}$

\section{Hubungan usia dengan MDR-TB}

Pasien MDR-TB dan non MDR lebih banyak yang berusia 15 -35 tahun, masing masing sebanyak 15 orang $(30,6 \%)$ dan 34 orang $(69,4 \%)$. Namun hasil analisis bivariat denggan uji chi-square didapatkan nilai $\mathrm{p}$ $=0,785(\mathrm{p}=<0,05)$ dengan demikian tidak didapatkan hubungan yang bermakna antara usia dengan MDR-TB.

Hasil penelitian ini serupa dengan hasil penelitian yang dilakukan di RS Persahabatan pada tahun 2009 menggunakan analisa univariat, dari 101 pasien MDR-TB ditemukan paling banyak pada rentang usia 25-34 tahun sebanyak 35,6\%. MDR-TB sering ditemukan pada usia produktif dikarenakan pada usia tersebut sangat rentan mendapat transmisi kuman TB karena pasien mudah berinteraksi dengan orang lain, mobilitas yang tinggi dan memungkinkan untuk menular ke orang lain serta lingkungan sekitar tempat tinggal. ${ }^{11}$ 
Hasil penelitian ini berbeda dengan studi case control yang dilakukan oleh Workicho dkk di Ethiophia bahwa usia berhubungan dengan MDR-TB didapatkan usia kurang dari 30 tahun berisiko 7 kali lebih besar menjadi MDR-TB dengan nilai OR adjusted sebesar 7,95\%. Perbedaan hasil penelitian ini dapat disebabkan oleh kurangnya jumlah sampel pada penelitian ini dan faktor-faktor perancu lainnya tidak di eksklusi serta perbedaan disain penelitian yang digunakan. ${ }^{13}$

Hubungan tingkat pendidikan dengan MDR-TB

Didapatkan kesamaan tingkat

Tabel 2. Uji analisis bivariat

\begin{tabular}{|c|c|c|c|c|c|c|c|}
\hline \multirow{3}{*}{ Variabel } & \multicolumn{4}{|c|}{ Status MDR-TB } & \multirow[t]{3}{*}{$\mathbf{p}$} & \multirow[t]{3}{*}{ OR } & \multirow[t]{3}{*}{$95 \% \mathrm{CI}$} \\
\hline & \multicolumn{2}{|c|}{ TB-MDR $(n=28)$} & \multicolumn{2}{|c|}{ TB-Non MDR $(n=60)$} & & & \\
\hline & $\mathbf{n}$ & $\%$ & $\mathbf{n}$ & $\%$ & & & \\
\hline \multicolumn{8}{|l|}{ Jenis Kelamin } \\
\hline Laki - Laki & 19 & $33,30 \%$ & 38 & $66,70 \%$ & $0,679^{\wedge}$ & 0,818 & $0,316-2,118$ \\
\hline Perempuan & 9 & $29 \%$ & 22 & $71 \%$ & & & \\
\hline \multicolumn{8}{|l|}{ Usia } \\
\hline $15-35$ & 15 & $30,60 \%$ & 34 & $69,40 \%$ & $0,785^{\wedge}$ & 1,133 & $0,460-2,791$ \\
\hline $\begin{array}{l}>35 \\
\text { Tingkat }\end{array}$ & 13 & $33,30 \%$ & 26 & $66,70 \%$ & & & \\
\hline $\begin{array}{l}\text { Pendidikan } \\
\text { Rendah }\end{array}$ & 3 & $15,80 \%$ & 16 & $84,20 \%$ & $0,090^{\wedge}$ & 3,03 & $0,804-11,426$ \\
\hline $\begin{array}{l}\text { Tinggi } \\
\text { Kebiasaan } \\
\text { Merokok }\end{array}$ & 25 & $36,20 \%$ & 44 & $63,80 \%$ & & & \\
\hline $\mathrm{Ya}$ & 19 & $59,40 \%$ & 13 & $40,60 \%$ & $0,000^{\wedge}$ & 7,632 & $2,799-20,812$ \\
\hline $\begin{array}{l}\text { Tidak } \\
\text { Konsumsi } \\
\text { Alkohol }\end{array}$ & 9 & $16,10 \%$ & 47 & $83,90 \%$ & & & \\
\hline Ya & 11 & $73,30 \%$ & 4 & $26,70 \%$ & $0,000 \#$ & 9,059 & $2,553-32,146$ \\
\hline Tidak & 17 & $23,30 \%$ & 56 & $76,60 \%$ & & & \\
\hline \multicolumn{8}{|l|}{ Status Gizi } \\
\hline Underweight & 15 & $51,70 \%$ & 14 & $48,30 \%$ & $0,005^{\wedge}$ & 3,791 & $1,461-9,839$ \\
\hline $\begin{array}{l}\text { Normal } \\
\text { Diabetes } \\
\text { Melllitus }\end{array}$ & 13 & $22 \%$ & 46 & $78 \%$ & & & \\
\hline $\mathrm{Ya}$ & 3 & $75 \%$ & 1 & $25 \%$ & $0,093 \#$ & 7,08 & $0,702-71,398$ \\
\hline Tidak & 25 & $29,80 \%$ & 59 & $70,20 \%$ & & & \\
\hline \multicolumn{8}{|l|}{ HIV } \\
\hline Ya & 1 & $25 \%$ & 3 & $75 \%$ & $1,000 \#$ & 0,704 & $0,070-7,083$ \\
\hline $\begin{array}{l}\text { Tidak } \\
\text { Motivasi }\end{array}$ & 27 & $32,10 \%$ & 57 & $67,90 \%$ & & & \\
\hline $\begin{array}{l}\text { Penderita } \\
\text { Rendah }\end{array}$ & 20 & $87 \%$ & 3 & $13 \%$ & $0,000^{\wedge}$ & 47,5 & $\begin{array}{l}11,466- \\
196,772\end{array}$ \\
\hline $\begin{array}{l}\text { Tinggi } \\
\text { Kepatuhan } \\
\text { Minum Obat }\end{array}$ & 8 & $12,30 \%$ & 57 & $87,70 \%$ & & & \\
\hline Kepatuhan rendah & 23 & $56,10 \%$ & 18 & $43,90 \%$ & $0,000^{\wedge}$ & 10,733 & $3,524-32,687$ \\
\hline Kepatuhan tinggi & 5 & $10,60 \%$ & 42 & $89,40 \%$ & & & \\
\hline
\end{tabular}


pendidikan terbanyak antara pasien MDRTB dan non-MDR yaitu tingkat pendidikan tinggi, masing-masing sebanyak 25 orang $(36,2 \%)$ dan 44 orang $(63,8 \%)$. Hasil analisa bivariat uji statistik chi-square didapatkan nilai $\mathrm{p}=0,090(\mathrm{p}=<0,05)$ dengan derajat odd ratio sebesar 3,030. Berdasarkan uji statistik chi-square tidak didapatkan hubungan yang bermakna antara tingkat pendidikan dengan MDR-TB

Penelitian yang dilakukan oleh Fitriani menunjukkan hal yang sama bahwa tingkat pendidikan tidak berhubungan dengan terjadinya MDR-TB dengan hasil analisis bivariat dengan uji chi-square didapatkan $\mathrm{p}$ $=0,79 \cdot{ }^{14}$ Studi yang dilakukan oleh Bagiada, memberikan hasil bahwa ketidakpatuhan penderita dalam menjalani pengobatan tuberkulosis tanpa memandang status intelektualitas penderita. Tidak bermaknanya faktor tingkat pendidikan disebabkan karena tidak selamanya penderita yang berpendidikan dasar tingkat pengetahuannya tentang tuberkulosis rendah, dan juga tidak semua yang berpendidikan menengah ke atas tingat pengetahuannya tentang tuberkulosis tinggi. Saat ini sudah banyak media yang memberikan informasi tentang pentingnya pengobatan tuberkulosis. ${ }^{15}$

\section{Hubungan kebiasaan merokok dengan MDR-TB}

Berdasarkan hasil penelitian didapatkan 19 pasien MDR-TB (59,4\%) dan 13 pasien TB non MDR $(40,6 \%)$ yang memiliki kebiasaan merokok. Dari hasil tersebut ditemukan bahwa kebiasaan merokok lebih banyak pada pasien MDR-TB dibandingkan pasien TB non MDR. Terdapat hasil yang bermakna antara kebiasaan merokok dengan MDR-TB. Hasil analisa bivariat uji statistik chi-square didapatkan nilai $\mathrm{p}=0,000(\mathrm{p}=$ $<0,05$ ) dengan derajat OR sebesar 7,63. Hal ini menunjukkan bahwa kebiasaan merokok memiliki resiko 7,63 kali lebih besar untuk menderita MDR-TB dibandingkan dengan pasien TB yang tidak memiliki kebiasaan merokok.

Hasil penelitian ini sejalan dengan penelitian yang dilakukan oleh Marahatta dkk menyebutkan bahwa merokok merupakan faktor risiko terjadinya MDR-TB $(p=0,04$ dan OR sebesar 4,5). Hasil ini semakin diperkuat dengan fakta bahwa subjek penelitian sudah mengonsumsi rokok sejak mereka berusia muda. $^{16}$

Kebiasaan merokok dapat membuat seseorang lebih mudah terinfeksi TB. Kebiasaan merokok akan menyebabkan rusaknya mekanisme pertahanan mucocilliary clearance.Asap rokokjuga akan meningkatkan tahanan jalan napas akibat obstruksi pada saluran napas dan menghambat kerja makrofag pada alveolus. Hal ini membuat pasien yang merokok memiliki respon yang lebih buruk dalam menjalani pengobatan TB sehingga dapat jatuh dalam kondisi MDR-TB. ${ }^{17}$

\section{Hubungan konsumsi alkohol dengan MDR- TB}

Didapatkan 11 pasien MDRTB $(73,3, \%)$ dan 4 pasien TB non MDR $(26,7 \%)$ yang memiliki riwayat konsumsi alkohol. Dari hasil tersebut ditemukan bahwa konsumsi alkohol lebih sering terjadi pada pasien MDR-TB dibandingkan pasien TB non MDR. Terdapat hasil yang bermakna antara konsumsi alkohol dengan MDR-TB. Hasil analisa bivariat uji statistik fisher didapatkan nilai $p=0,000(p=<0,05)$ dengan OR sebesar 9,05 . Hal ini menunjukkan bahwa konsumsi alkohol beresiko 9,05 kali lebih besar untuk menderita MDR- TB dibandingkan dengan pasien TB yang tidak mengonsumsi alkohol.

Hasil ini serupa dengan penelitian yang dilakukan oleh Massi dkk. Pada penelitian ini didapatkan bahwa orang yang mengonsumsi alkohol memiliki risiko 4 kali lebih besar untuk menderita MDR-TB. Penelitian ini menyebutkan bahwa riwayat konsumsialkohol adalah salah satu karakterisitik yang sering ditemukan pada pasien dengan MDR-TB. Beberapa studi juga mengemukakan bahwa konsumsi alkohol dapat membuat kuman TB bertahan lebih lama di dalam makrofag akibat melemahnya proses fagositosis yang dilakukan oleh makrofag. ${ }^{18}$

\section{Hubungan status gizi dengan MDR-TB}

Didapatkan perbedaan karakteristik 
status gizi pada pasien MDR-TB dan TB non MDR. Status gizi pasien MDR-TB lebih banyak yang underweight yaitu sebanyak 13 pasien $(51,7 \%)$, sedangkan IMT normal lebih banyak ditemukan pada pasien TB non-MDR sebanyak 46 orang $(78 \%)$. Terdapat hasil yang bermakna antara status gizi dengan MDR-TB $(\mathrm{p}=0,005)$ dengan OR sebesar 3,79. Hal ini menunjukkan bahwa status gizi underweight memiliki resiko 3,79 kali lebih besar untuk menderita MDR -TB dibandingkan dengan status gizi normal.

Hasil penelitian ini sesuai dengan penelitian Fauziah tahun 2013 yang menunjukkan responden yang menderita MDR TB lebih banyak diderita oleh responden yang memiliki IMT $<18,5$. Status gizi yang memiliki hubungan kuat dengan kejadian MDR-TB dengan OR adjusted 3,3 yang artinya pasien TB dengan IMT $<18,5$ berisiko 3,2 kali menderita MDR-TB.

Pasien TB yang underweight memiliki risiko yang lebih tinggi untuk kambuh setelah pada pengobatan TB atau berkembang menjadi infeksi TB laten. Status gizi yang buruk dapat menyebabkan kuman yang semakin cepat berkembang biak sehingga menghambat kejadian konversi, selain itu juga menyebabkan daya tahan tubuh yang rendah sehingga mempersulit penyembuhan dan memudahkan kekambuhan kembali. ${ }^{5}$

\section{Hubungan diabetes melittus dengan MDR- TB}

Berdasarkan hasil penelitian didapatkan 3 pasien MDR-TB (75\%) dan 1 pasien TB non MDR (25\%) yang menderita DM. Hasil analisa bivariat uji statistik fisher didapatkan nilai $\mathrm{p}=0,093 \quad(\mathrm{p}=<0,05)$ dengan demikian tidak didapatkan hubungan yang bermakna antara DM dengan MDR-TB

Pada saat penelitian, dilakukan wawancara pada pasien yang menderita DM tentang riwayat konsumsi obat DM, didapatkan bahwa pasien mendapatkan obat DM dari puskesmas dan rutin mengonsumsinya sehingga dapat diasumsikan pasien memiliki DM yang terkontrol. Berdasarkan penelitian yang dilakukan oleh Song dkk menjelaskan bahwa pasien dengan TB dengan DM tidak berhubungan dengan MDR-TB apabila pasien sudah mendapatkan terapi DM sebelumnya atau pasien memiliki DM yang terkontrol. Pasien dengan DM yang terkontrol tentunya akan lebih jarang mengalami hiperglikemia sehingga memengaruhi hasil dari pengobatan TB. ${ }^{19}$

\section{Hubungan HIV dengan MDR-TB}

Berdasarkan hasil penelitian didapatkan 1 pasien MDR-TB (25\%) dan 3 pasien TB non MDR (75\%) yang menderita HIV. Hasil analisa bivariat uji statistik fisher didapatkan nilai $\mathrm{p}=1,000(\mathrm{p}=<0,05)$ dengan demikian tidak didapatkan hubungan yang bermakna antara HIV dengan MDR-TB.

Hasil ini berbeda dengan studi metaanalisis Yonathan dkk, bahwa terdapat hubungan yang signifikan antara HIV dengan MDR-TB primer dan tidak signifikan dengan MDR-TB sekunder. Hal ini dikarenakan orang dengan HIV memiliki daya tahan tubuh yang lebih lemah sehingga mudah terinfeksi apabila kontak dengan pasien MDR-TB. ${ }^{17}$

Penelitian yang dilakukan oleh Eldholm dkk juga membuktikan bahwa HIV memiliki hubungan dengan MDR-TB primer didapatkan bahwa pasien dengan HIV beresiko mengidap TB, namun HIV tidak bertanggung jawab atas mutasi kuman TB yang terjadi pada pasien dengan TB-koinfeksi HIV yang dapat membuatnya menjadi MDRTB. ${ }^{20}$

Hasil penelitian ini tidak sejalan dengan kedua penelitian sebelumnya karena subjek penelitian yang diambil adalah pasien MDR sekunder yang memiliki riwayat pengobatan TB sebelumnya dan subjek penelitian yang menderita HIV tidak cukup banyak.

\section{Hubungan motivasi penderita dengan MDR-TB}

Berdasarkan hasil penelitian didapatkan perbedaan karakteristik dalam motivasi penderita pada pasien MDR-TB dan TB non MDR. Motivasi yang rendah 
dalam melakukan pengobatan terdapat pada kebanyakan pasien MDR-TB sebanyak 20 orang $(87 \%)$, sedangkan pada pasien TB nonMDR lebih banyak yang memiliki motivasi tinggi sebanyak 57 orang $(87,7 \%)$. Terdapat hasil yang bermakna antara motivasi penderita dengan MDR-TB. Hasil analisa bivariat uji statistik chi-square didapatkan nilai $\mathrm{p}=$ $0,000(\mathrm{p}=<0,05)$ dengan OR sebesar 47,5. Hal ini menunjukkan bahwa motivasi rendah dalam melakukan pengobatan TB memiliki resiko 47,5 kali lebih besar untuk menderita MDR-TB dibandingkan dengan penderita TB dengan motivasi tinggi.

Hasil penelitian ini serupa dengan penelitian Sarwani, didapatkan hubungan antara motivasi rendah dengan MDRTB. Hasil analisis bivariat dan multivariat menunjukkan ada hubungan antara motivasi dengan MDR-TB. Berdasarkan penelitian tersebut, pasien yang mempunyai motivasi rendah untuk minum obat mempunyai risiko 4,2 kali lebih besar untuk menderita MDR-TB dibandingkan yang mempunyai motivasi yang tinggi.

Alasan utama gagalnya pengobatan adalah pasien tidak mau minum obat secara teratur dalam waktu yang diharuskan. Lamanya waktu pengobatan TB paru yang harus dilakukan selama 6 bulan, dapat saja dijadikan beban oleh penderita sehingga mereka malas untuk melanjutkan proses pengobatan. Adapun penderita dengan motivasi yang kuat untuk sembuh dari penyakit akan tetap melakukan pengobatan secara teratur. Kurangnya motivasi dan kesadaran ini dapat terjadi karena kurangnya pengetahuan penderita tentang penyakitnya dan bagaimana mengobatinya. ${ }^{5}$

\section{Hubungan kepatuhan minum obat penderita dengan MDR-TB}

Terdapat hubungan yang signifikan antara kepatuhan minum obat dengan MDR$\mathrm{TB}$, berdasarkan hasil analisa bivariat uji statistik chi-square didapatkan hasil bahwa nilai $\mathrm{p}=0,000$ dengan $\mathrm{OR} 10,73$. Hal ini menunjukkan bahwa pasien TB dengan kepatuhan minum obat rendah memiliki resiko 10,73 kali lebih besar untuk menjadi MDR-
TB dibandingkan dengan pasien dengan kepatuhan minum obat tinggi.

Hasil penelitian ini sesuai dengan penelitian Nurismi, yaitu terdapat hubungan yang bermakna antara tingkat kepatuhan pengobatan dengan kejadian MDR TB di RSUD Labuang Baji Makassar dan besarnya risiko dapat dilihat dari nilai $\mathrm{OR}=28.02$ yang artinya responden dengan tingkat kepatuhan pengobatan yang tidak baik kemungkinan terjadi MDR TB sebesar 28 kali dibandingkan dengan responden dengan tingkat kepatuhan baik. ${ }^{12}$

Kepatuhan pengobatan merupakan hal yang penting untuk menghindari terjadinya MDR-TB dan kegagalan dalam pengobatan.

Kepatuhan pasien sangat dituntut dalam menjalani pengobatan jangka panjang ini. Ketidakpatuhan dalam pengobatan menjadi faktor penting dalam berkembangnya resistensi. Faktor-faktor tertentu, seperti konsumsi alkohol, pengobatan yang kompleks, efek samping obat dan waktu pengobatan yang butuh waktu yang lama sehingga membuat pasien memutuskan untuk berhenti minum obat menjadi faktor ketidakpatuhan terhadap pengobatan. Ketidaktaatan pasien TB dalam minum obat secara teratur tetap menjadi hambatan untuk mencapai angka kesembuhan yang tinggi Tingginya angka putus obat akan mengakibatkan tingginya kasus resistensi kuman terhadap obat antituberkulosis (OAT). ${ }^{5}$

\section{Keterbatasan penelitian}

1. Disain penelitian ini adalah studi cross sectional, sehingga faktor risiko yang terdapat pada pasien dinilai saat dilakukannya pengambilan. Diperlukan disain studi lain seperti cohort untuk menilai secara lebih jelas perkembangan faktor-faktor resiko yang menyebabkan terjadinya MDR-TB.

2. Tidak dilakukan pemeriksaan kadar gula darah dan CD4 untuk menentukan berat ringannya penyakit DM dan HIV akibat keterbatasan biaya dan pengetahuan. 


\section{KESIMPULAN}

Terdapat hubungan yang bermakna antara motivasi penderita $(\mathrm{p}=0,000 ; \mathrm{OR}=$ $47,5)$, kepatuhan minum obat $(\mathrm{p}=0,000$; OR $=10,7)$ konsumsi alkohol $(\mathrm{p}=0,000$; OR $=$ $9,059)$, kebiasaan merokok $(\mathrm{p}=0,000$; OR $=7,632)$, status gizi $(\mathrm{p}=0,005 ; \mathrm{OR}=3,791)$ dengan MDR-TB. Tetapi tidak didapatkan hubungan yang bermakna karena $p<0,05$ antara jenis kelamin $(\mathrm{p}=0,679)$, usia $(\mathrm{p}=$ $0,785)$, tingkat pendidikan $(\mathrm{p}=0,090)$, Diabetes mellitus $(p=0,093), \operatorname{HIV}(p=1,000)$ dengan MDR-TB.

\section{UCAPAN TERIMAKASIH}

Ucapan terima kasih sebesar-besarnya kepada kedua orang tua, dr. Titi Moertolo, Sp.KK, dr. Tubagus Ferdi Fadilah Sp.A, M.Kes, seluruh staf bagian diklat dan Poli TB Puskesmas Kecamatan Kramat Jati, Kecamatan Ciracas, Kecamatan Makasar, dan Kecamatan Pasar Rebo yang telah mengizinkan dan membantu peneliti untuk melakukan pengambilan data skripsi.

\section{DAFTAR REFERENSI}

1. Hapsari AR., Faridah F., Balwa AF., Saraswati LD. Analisis kaitan riwayat merokok terhadap pasien tuberkulosis paru (TB paru) di puskesmas srondol. Jurnal Ilmiah Mahasiswa. 2013. 3(2): 48.

2. Steingart K.R., Schiller I., Horne D.J., Pai M., Boehme C.C., Dendukuri N. Xpert ${ }^{\circledR}$ MTB/RIF assay for pulmonary tuberculosis and rifampicin resistance in adults. Cochrane Database of Systematic Reviews. 2014. Issue 1.

3. World Health Organization. Global tuberculosis report 2016. Geneva: WHO; 2016.

4. Kementerian Kesehatan Republik Indonesia. Profil Kesehatan Indonesia 2016. Jakarta: Kemenkes RI; 2016.

5. Sarwani D., Nurlela S., Zahrotul I. Faktor risiko multidrug resistant tuberculosis (MDR-TB). Jurnal Kesehatan Masyarakat.
2012. 8(1): 60-6.

6. Faustini A. Hall AJ, Perucci CA. Risk factors for multidrug resistant tuberculosis in Europe: a systematic review. Thorax. 2006.61:158-63

7. Astri SDA. Masalah Tuberkulosis Resisten Obat. 2014. Cermin Dunia Kedokteran.41(4): 248-49

8. Soepandi PZ. Diagnosis dan Penatalaksanaan MDR-TB . 2010. Cermin Dunia Kedokteran. 180. 497-501

9. Dinas Kesehatan Provinsi DKI Jakarta. Indonesia darurat tuberkulosis. Available at http://dinkes.jakarta.go.id/indonesiadarurat-tuberkulosis/. Accessed at 12 May 2017

10. Balaji V., Daley P., Azad AA., Sudarsaman T., Michael JS.,Sahni RD. et al. Risk factors for MDR and XDR-TB in a tertiary referral hospital in India. PLoS ONE. 2010. 5(3).

11. Munir S.M., Nawas A., Soetoyo D.K. Pengamatan pasien tuberkulosis paru dengan multidrug resistant (TB-MDR) di poliklinik paru RSUP persahabatan. J Respir Indo. 2010. 30(2): 93-104.

12. Munawwarah F, Leida I, Wahiduddin. Gambaran faktor risiko pengobatan pasien TB- MDR RS Labuang Baji Kota Makassar tahun 2013. Hasanuddin University Repository. 2013

13. Workicho A, Kassahun W, Alemseged F. Risk factors for multidrug resistant among tuberculosis patients: a case control study. Infect drug resist. 2017. 10: 91-96

14. Fitriani E. Faktor risiko yang berhubungan dengan kejadian tuberkulosis paru. UNNES Journal Public of Health 2. 2013. 2(1)

15. Bagiada I.M., Primasari N.L.P. Faktorfaktor yang mempengaruhi tingkat ketidakpatuhan penderita tuberkulosis dalam berobat di poliklinik DOTS RSUP Sanglah Denpasar. Journal of Internal Medicine. 2010. 11(3)

16. Marahatta SP., Adhikari B., Mishra SR., Raut S., Ramasoota P., Malla P., Kaewkungwal J., Singhasivanon P (2015) Association of Previous Smoking Habit 
and Perceived Social Discrimination with the Risk of Multi - Drug Resistant Tuberculosis in Central Nepal. Journal of Nepal Health research Council. 13(29): 95-101

17. Smit VZ, Pai M. Global lung health: The colliding epidemics of tuberculosis, tobacco smoking, HIV and COPD. Europe Respiration Journal. 2010. 35: 27-33

18. Massi MN., Wahyuni S., Malik H., Anita., Yusuf I., Leong FJ., Dick T., Phyu S (2011) Drug resistance among tuberculosis patients attending diagnostic and treatment centres in Makassar, Indonesia. International Journal Tuberculosis Lung Disease. 15(4): 489-495

19. Song Q., Zhang G., Jiang H., Ren Y., Lu X (2016) Imaging Features of Pulmonary CT in Type 2 Diabetic Patients with Multidrug Resistant Tuberculosis. PLoS ONE. 11(3) 20. Mesfin YM, Hailemariam D, Biadglign S, Kibret KT. Association between HIV/AIDS and multi drug resistance Tuberculosis: a systematic review and meta-analysis. 2014. PLoS ONE. 9(1). 